City University of New York (CUNY) CUNY Academic Works

2016

\title{
Affirmative Action Debates in American Government Introductory Textbooks
}

Sherrie L. Wallace

University of Louisville

Marcus D. Allen

CUNY Guttman Community College

\section{How does access to this work benefit you? Let us know!}

More information about this work at: https://academicworks.cuny.edu/nc_pubs/88

Discover additional works at: https://academicworks.cuny.edu

This work is made publicly available by the City University of New York (CUNY).

Contact: AcademicWorks@cuny.edu 


\title{
Affirmative Action Debates in American Government Introductory Textbooks
}

\section{Sherri L. Wallace' and Marcus D. Allen²}

\begin{abstract}
Affirmative action debates remain hotly contested across America. Given how the topic is presented in respective disciplines and core textbooks, students are often misinformed. Introductory textbooks may be one of the few places where students are exposed to significant discussions on affirmative action. In this study, we examine affirmative action policy in American government introductory textbooks published between 2005 and 2014. Our study is modeled on previous, similar analyses of introductory textbooks. We use content analysis to examine the extent to which affirmative action discussions challenge or reinforce affirmative action myths and meritocracy. We conclude that textbook discussions that emphasize the policy intent over policy interpretation tend to debunk affirmative action myths and meritocracy. Meaning, the policy intent focus-presented as the "equality of opportunity" view-challenges historical discrimination and racism while the policy interpretation focus - presented as the "equality of outcome" view-seems to reinforce negative views.
\end{abstract}

\section{Keywords}

affirmative action, Clinton directive, myths, meritocracy

\footnotetext{
'University of Louisville, KY, USA

${ }^{2}$ CUNY, Stella \& Charles Guttman Community College, New York City, USA

\section{Corresponding Author:}

Sherri L. Wallace, University of Louisville, Ford Hall, Room 205, Louisville, KY 40292, USA.

Email: sherri.wallace@louisville.edu
} 


\section{Introduction}

The history of affirmative action policy consists of a broad collection of executive orders, bureaucratic decisions, court cases, and state legislation designed to eliminate unlawful discrimination of applicants to educational programs or professional employment, to remedy the results of such prior discrimination, and to prevent discrimination in the future. In an effort to expand opportunity for underrepresented groups that have been subject to institutionalized discrimination, President Clinton's directive (1995) - "Mend It, Don't End It" - outlined specific criteria for affirmative action policy stating, "any program must be eliminated or reformed if it: a) creates a quota; b) creates a preference for unqualified individuals; c) creates reverse discrimination; and d) continues even after its equal opportunity purposes have been achieved" (Beeman, Chowdhry, \& Todd, 2000, p. 99; Stephanopoulos \& Edley, 1995). After Clinton, the George W. Bush administration, seeking to dismantle affirmative action, filed, to no avail, two amicus curiae briefs with the Supreme Court regarding the use of race in admissions in the University of Michigan cases. The Obama administration's Executive Order 13583 has not altered the Clinton directive, which to date remains the most explicit statement on affirmative action policy. Although targeted legislation has expanded protections beyond underrepresented racial/ethnic groups in education and employment to include women, people of a certain age, people with disabilities, and veterans, the actual policy intent of affirmative action remains "a source of confusion for the public in the United States"; particularly, when affirmative action debates are presented within a race-only paradigm - and without the inclusion of gender, age, disability, or other protected categories - the program is commonly portrayed or perceived as a policy for "blacks only" (Beeman et al., 2000, pp. 9, 104), distorting the policy directive.

We know that affirmative action has long been associated with "reverse discrimination," quota systems, lowering of standards, and excessive or unnecessary federal interference in the internal policies and practices in areas of public education and employment. As early as 1960s, academicians began to present arguments to counter such associations; moreover, because the policy prior to 1995 lack clear definition, organized challenges by opponents of the policy sought to modify, restrict, and eliminate affirmative action programs, primarily in the area of education. From the initial decision on its use in admissions policy in the Regents of the University of California v. Bakke (1978), the battle over ending affirmative action has been waged heavily in the courts, where judges have failed to agree on interpretations of basic legal precedents, resulting in "precariously . . . close split decisions from the Supreme Court ever since” (Beeman et al., 2000, p. 99). As a consequence, 
affirmative action challengers have successfully promoted public campaigns in individual states, in the name of "civil rights," to get voters to approve state initiatives and referendums banning the use of affirmative action altogether, arguing that it is antithetical to a color-blind society or hurts those it intends to help (Sander \& Taylor, 2012).

We model the work by Beeman et al. (2000) that investigated the treatment of affirmative action in 35 introductory sociology textbooks. Using modern racism or "racial resentment" studies to explain Whites' attitudes toward affirmative action and equal opportunity, their study effectively demonstrated when affirmative action is defined or discussed-absent the modern racism theoretical context - myths about affirmative action go unchallenged or are reinforced (Beeman et al., 2000, p. 102). In this study on American government introductory textbooks, we use content analysis to examine the extent to which affirmative action discussions challenge or reinforce affirmative action myths and meritocracy. We conclude that textbook discussions that emphasize the policy intent over policy interpretation tend to debunk affirmative action myths and meritocracy. Meaning, the policy intent focus - presented as the "equality of opportunity" view — challenges historical discrimination and racism while the policy interpretation focus - presented as the "equality of outcome" view-seems to reinforce prevailing negative views overall.

\section{Affirmative Action Myths and Meritocracy}

In the wake of the confusion about affirmative action policy, opponents have often perpetuated myths to gain public support and eliminate the program. The myths say that affirmative action policy emphasizes the use of "quotas" or "preferential treatment"; creates "reverse discrimination"; gives minorities "special advantages" they no longer need; gives jobs to "unqualified" candidates over "qualified" candidates; undermines the "self-esteem of people of color or women"; works against the creation of a "color-blind" society because it is "race counting"; and promotes "social engineering by liberal Democrats" (Beeman et al., 2000, p. 99; Plous, 2003; Sander \& Taylor, 2012). These myths appeal to opponents of affirmative action because they reinforce attitudes held predominately by Whites, which stokes the "racist fears of many Whites and may confuse the public into believing or reaffirming the myth that affirmative action is a program solely for racial minorities . .." (Beeman et al., 2000, p. 100). In fact, when affirmative action emerges in college classroom discussions, it is often the "topical deal-breaker" because of the ways in which the topic has been presented in the public discourse, and it generates "resistance, paralysis and rage" among students, who lack full 
understanding of the actual policy intent, resulting in heightened resentment toward people of color (Gayles, 2004, p. 41) without fully interrogating the tendency for all social groups to "support broader based benefit programs, especially those which may benefit themselves" (DiTomaso, Parks-Yancy, \& Post, 2011, p. 2).

Early studies on racial attitudes have been used to explain Whites' attitudes toward race and race-conscious policies. White Americans are often widely supportive of principles of equality opportunity, but widely opposed to the implementation of government policies that are supposed to ensure equal treatment such as affirmative action or "racially ambiguous" social welfare policy (DiTomaso et al., 2011, p. 3). Sniderman and Piazza (1993) found in their study of the response of White students to affirmative action that these students' views are often not caused by "deep-seated, often denied, negative feelings about blacks," but, on the contrary, negative feelings about affirmative action policy may cause more negative feelings toward Blacks (p. 102). The logic of this "old racism" paradigm - used as a defense of White privilege or "group self-interests" - was that Whites tended to oppose affirmative action or race-conscious policies because they considered Blacks to be "biologically inferior," based on the "traditional" individualism view (Kluegel, 1990, p. 513). The "old racism" may have dissipated; however, "racist attitudes are still prevalent [and have] become more subtle" (Gainous, 2012, p. 252). Today, many Whites' attribute Black-White socioeconomic disparities to a "motivational individualism" or the "lack of will or effort on the part of blacks," which is referred to as "symbolic racism" (Hughes, 1997; Kinder \& Sears, 1981; Kluegel, 1990, p. 51), "laissez faire racism" (Bobo, Kluegel, \& Smith, 1997), or modern racism expressed as "racial resentment."

Recurrent themes found in studies on racial resentment emphasize that because most Whites do not perceive themselves as racist or hold racist views, many profess that race discrimination is no longer a problem, which explains why Whites often perceive affirmative action as "preferential treatment" or "reverse discrimination" and violate American core principles such as "equality," "individualism," and "meritocracy," rather than as a possible remedy for past discrimination (Beeman et al., 2000, p. 101). Now that "prejudice is expressed in the language of American individualism" (Kinder \& Sanders, 1996, p. 106), "Whites' opposition to race-conscious policy is based on the conjunction of racism and a belief in the principle of hard work, . . self-reliance [and] opposition to big government or limited-government values" (Gainous, 2012, p. 252). Thus, Whites' disapproval of race-conscious policy "provides more cover than one based on individualist claims" (Gainous, 2012, p. 253), which allows Whites to "protect their institutional privileges without admitting racial privilege" (Beeman et al., 2000, p. 101). Thus, divergent views emerge. 
Studies have revealed that White Americans' divergent views regarding equal opportunity and affirmative action support "attribution error," that is, Whites, with notable class differences, tend to "privilege dispositional characteristics in themselves and minimize or forget the situational factors that contributed to their own success," believing that "their lives are the products of their own efforts" (DiTomaso et al., 2011, p. 12; Pettigrew, 1979). The ultimate attribution error expressed by the respondents in the study was reinforced by their own access to (and the invisibility of) social and cultural capital, which enabled them to gain advantages in their own careers even if they were not "the best person" at the time they were hired because Whites do not see the "the structural advantages and special privileges that [they] may enjoy, especially when these violate what are our ostensible norms about fairness and equity" (p. 13). Thus, when Whites receive help to "get in the door" or are given the chance to "prove themselves," although they themselves are not meeting the standard of being the "best person" for the job (DiTomaso et al., 2011, p. 13), they tend to expect African Americans and other non-Whites to meet traditional, "meritocratic" standards in college admissions or employment.

Significant evidence of attribution error was found in a study by Samson (2013), who found that in California, where Whites are no longer the plurality, White perception of "group threat" from Asian students influences ideas about admissions criteria in prestigious, selective California universities. The findings suggested that Whites will alter the individual-based evaluation standard (based on qualifications or a meritocratic distribution of opportunities and rewards) to produce a double standard (structural advantage or special privileges) benefitting Whites because

a change in group position does prompt members of the dominant group to selectively change the standard of evaluation in order to slightly lower the bar for co-ethnics on one criterion, while slightly raising the bar on a second criterion to obstruct a successful decision outcome for members of the ascending out-group. (Samson, 2013, p. 383)

Such research is important because it illuminates how institutional or race privilege is mediated through benign affirmative action, such as "legacy admissions," but does little to challenge myths about the policy.

We know that legacy admissions, the admission of children or relatives of alumni benefactors, often go unchallenged by opponents of affirmative action and in textbook discussions. Previous studies revealed that legacies have a 3 times greater chance of admission to prestigious universities than non-legacy students, even when "they were less qualified than non-legacy students" (Pincus, 1996, p. 103). In fact, a study of Harvard admissions found that the marginally qualified legacies outnumbered the total of Black, Mexican 
American, Native American, and Puerto Rican enrollees altogether (Larew, 1991). However, this preferential treatment is viewed as perfectly legal because it benefits White middle- and upper-income individuals and no one is "outraged" (Pincus, 1996, p. 103). In this study, we posit that the inclusion of modern racism theory could illuminate institutional or race privilege - disguised as meritocracy - in textbook discussions on affirmative action by accentuating the acceptance of legacy admissions that is often ignored when discussing equal treatment.

\section{Previous Studies on Introductory Textbooks}

Beeman et al. (2000) argued the logical place to explore the nature and intent of affirmative action policy is in an introductory course that devotes considerable attention to race, ethnic, and gender stratification and attempts by society to address past and continued discrimination against these social groups. In political science, students will study the fundamental principles and values of the American political system. Although students "expect that their course materials are truthful, factual, unbiased, and without stereotypical depictions" (Eisenstein \& Clark, 2013, p. 90), most of the major textbooks used in American government introductory courses mirror the discipline of political science, which typically studies institutions and elites as primary decision makers and reinforces values that privilege the powerful and perpetuates stereotypes about underrepresented groups (Artz \& Murphy, 2000; Hardin, Dodd, \& Lauffer, 2006). Because textbooks are "instrument[s] that help instructors design their courses, provide uniform content, and provide the basis of class discussion" (Hardin et al., 2006, p. 433), they are powerful indicators of what is legitimate knowledge and material in most courses. It is not taken as given that textbooks construct reality, by selecting and organizing knowledge by screening it. They provide selective access to ideas and information that are interpreted by students as natural or true (Apple \& Christian-Smith, 1991; Hardin et al., 2006; Sleeter \& Grant, 1991). Students use knowledge learned from introductory textbooks in a particular field to interpret or reinforce information they receive later (Hogben \& Waterman, 1997). The explicit messages received underscore cultural values through symbolic representations that confer legitimacy on the dominant social groups while diminishing or ignoring other types of knowledge (Sleeter \& Grant, 1991). More importantly, as Cassese, Bos, and Schneider (2014) surmise, the lack of content on underrepresented groups can lead students of marginalized identities to

view their own interests as uninteresting and falling outside of the mainstream

... [because they themselves] are particularly attuned to these kinds of 
messages, tending to internalize stereotypes that are reinforced in both their academic and social experiences. (p. 267)

Studies of introductory textbooks across various fields find weak or virtually absent discussion of social class, disability, the intersections of gender and race (Sleeter \& Grant, 1991), and participation in the political process by all racial, ethnic groups and women (Prestage, 1994). One study found racial biases in the portrayal of poverty and "race coding" via media images (Clawson, 2003; Clawson \& Kegler, 2000; Clawson \& Trice, 2000). Another study identified a tendency to "ghettoize" and marginalize particular racial, ethnic groups and women into one or two chapters (Stone, 1996). Foster (1999) found the use of "mentioning" (p. 271) - the phenomenon where a textbook will add content on racial, ethnic groups in a sidebar or focus box, without incorporating the information into the central message of the text. Sleeter and Grant (1991) saw a disregard for the complexities within the social groups or involving interactions among them. Textbooks in business and economics were found to have minimal discussion on the social economy and its effect on social groups (Myers \& Stocks, 2010).

Recent studies of American government textbooks, in particular, have called for the need to broaden coverage beyond the "Civil Rights" chapters to address stereotypical images or depictions of African Americans (Allen \& Wallace, 2010; Wallace \& Allen, 2008), Latinos (Monforti \& McGlynn, 2010), the religious perceptions and portrayal of people of faith (Eisenstein \& Clark, 2013), and to "mainstream" and make visible the "hidden curriculum" on gender content in introductory-level textbooks (Cassese \& Bos, 2013; Cassese et al., 2014) beyond the almost exclusive focus on "white middleclass women" (Olivo, 2012, p. 131), as well as to include the intersectionality of gender, race, ethnicity, and class. Cassese and Bos (2013) observe,

[v]arious social categories like race, gender, and sexual orientation are typically lumped together in a rather generic nod to [one's underrepresented] status. [In this respect,] race, ethnicity, and gender are employed simply as descriptive categories, rather than theorized or employed as analytic categories. (p. 217)

Moreover, discussions of race discrimination tend to begin after the Civil War and end with the affirmative action debate, which either follows the discussion on the African Americans or occurs at the end of that chapter (Wallace $\&$ Clayton, 2009). Subsequently, Wallace and Clayton (2009) found that content on affirmative action is usually presented as a dichotomous relationship between equal opportunity (equality of opportunity) and equal outcome (equality of results). This is meaningful because in texts where affirmative 
action follows directly from the historical narrative on African American political involvement, it is most often portrayed as a policy that is used to eliminate discrimination against mostly African Americans. Typically, much of the topic focus is on the controversy over the elimination of race barriers, with the in-text discussion often highlighting the dilemma of "reverse discrimination" toward White males. Thus, our study mirrors Beeman et al. (2000) and seeks to expand Wallace and Clayton's (2009) analyses.

\section{Method}

Our primary sample comprises 32 circulating introductory American government textbooks published from 2005 to 2014, from the first to 21 st complete, national editions. If discussion content on affirmative action was changed or altered since 2004, the content from the newer editions were used. All were published by nine of the leading publishers in American government textbooks (see the appendix). Building on the aforementioned studies, this study used content analysis - a method that involves the quantifying systematic evaluation of symbolic content within a text (Kolbe \& Burnett, 1991) - to examine American government introductory to address to what extent affirmative action discussions reinforce myths via use of coded language or meritocracy via "equal opportunity" versus "equal outcome" debates.

To determine the location and amount of coverage, we used the index citations, in-text discussions, and "side-bar mentions" as the measurement indicators (Ferree \& Hall, 1996). Specific coding instructions for terminology and phrases were provided to the coding team. To increase the reliability and validity of the coding schema, we checked the coding schema frequently throughout the process to avoid "drifting" (Schilling, 2006) and to guard against coder fatigue. There were three coders, who reviewed the coding framework several times to ensure the reliability and validity of the data. The variables were derived deductively and from previous research, which provides the basis for our coding rules. After counting the number of pages mentioning the research topics, we looked not only at the number of pages, but also where the pages were located. We sought to avoid as much as possible the reliability problems arising from the ambiguity of words/phrases when using word counts for the sake of convenience by reviewing context and pages to avoid double counts (Stone, 1996). The authors prefer definitive terms, such as "racially underrepresented groups"; however, our use of the word "minority" - in parenthetical or quotes - is deliberate and mirrors the actual terminology used in American government textbooks. We do not embrace nor endorse its use. We recognize that such term is hegemonic, refutable, and a misnomer. We do seek to challenge and prove its lack of 
Table I. Mention of Code Words or Phrases in Affirmative Action Discussions.

\begin{tabular}{|c|c|c|}
\hline Code words or phrases & $\begin{array}{l}\text { Policy intent } \\
\text { focus (\%) }\end{array}$ & $\begin{array}{l}\text { Policy interpretation } \\
\text { focus (\%) }\end{array}$ \\
\hline Controversial topic of debate & 47 & 53 \\
\hline Quotas, set-asides, numerical goals & 9 & 91 \\
\hline $\begin{array}{l}\text { Reverse discrimination or reverse } \\
\text { racism }\end{array}$ & 57 & 43 \\
\hline $\begin{array}{l}\text { Preference(s) or preferential } \\
\text { treatment }\end{array}$ & 19 & 81 \\
\hline $\begin{array}{l}\text { Un/fair advantage, color-blind } \\
\text { society, qualifications, merit-based }\end{array}$ & 47 & 53 \\
\hline $\begin{array}{l}\text { Equal opportunity (EO)/equal results } \\
\text { (ER) }\end{array}$ & 35 & 66 \\
\hline $\begin{array}{l}\text { Equal protection clause or } 14 \text { th } \\
\text { Amendment violation }\end{array}$ & 19 & 82 \\
\hline
\end{tabular}

Note. Percentages are derived from the number of mentions within the textbooks in the sample.

utility in our content analysis. The goal is to demonstrate how affirmative action debates are contextualized in American government textbooks in the absence of race theory. Our findings are reported below.

\section{Discussion}

Table 1 summarizes the results of our findings. It reveals that $53 \%$ of the American government textbooks introduced affirmative action debates or discussions as either "controversial" (12 textbooks), "extremely controversial" (1 textbook), "bitter controversy" (1 textbook), "contemporary controversy" (1 textbook), "long-running political dispute" (1 textbook), or "polarizing issue" (1 textbook).

Previous research has shown that because race is often a sensitive and controversial subject, publishers/editors, responding to pressure from their markets, may view the inclusion of these subjects as risky. At the same time, depending on how the discussions are presented, these "hot" topics can help sell textbooks (Wallace \& Allen, 2008). Taking this into consideration, we aimed to determine to what extent coded language, left unchallenged, was used to reinforce myths and meritocracy within the in-text discussions. Examples would include words and phrases such as (numerical) quota, setasides, reverse discrimination, preferential, compensatory treatment, colorblind society, merit-based, equal opportunity (i.e., procedural or equal 
treatment), equal outcome (i.e., substantive or equal results), or violation of equal protection.

Beeman et al. (2000) observed that the "most widespread myth about affirmative action ... is that it is essentially a quota program," which is both inaccurate and unconstitutional (p. 107). Our evidence supports their claim. We found that the majority (91\%) of the American government textbooks present affirmative action as a thinly veiled quota program, with references in discussions as involving some form of "numerical quota," "numerical goal," "timetables," or "set-asides" without challenging the myth. One textbook author even refers to affirmative action as "quota-based" program (see textbook: Volkomer, 2006, p. 320). Authors of another textbook use the word "quota" 10 times in five pages in the policy discussion without ever challenging the myth with substantive evidence (see textbook: Janda, Berry, \& Goldman, 2005, pp. 538-543). Interestingly, in an attempt to provide a legitimate critique of affirmative action without challenging the myth of quotas, the authors of one textbook implied that Frederick Douglass, the first Black Ambassador to Haiti in the 1870 s, was "one who would be against racial quota" (see textbook: O'Connor \& Sabato, 2006, p. 229), referring to a time when affirmative action did not exist. Of the 29 textbooks that present affirmative action as a thinly veiled quota program, only $11 \%$ present evidence to challenge the quota myth. One author equivocates, saying that "quotas, may be, but are not necessarily, involved in affirmative action policies" (see textbook: Lowi, Ginsberg, Shepsle, \& Ansolabehere, 2013, p. 149). Another author indicated that federal guidelines stipulate "no use of formal quotas in contracts . .." (see textbook: Ginsberg, Lowi, \& Weir, 2013, p. 190). One author debunks the quota myth altogether by stating the policy "does not require organizations to hire unqualified candidates nor qualified minorities ... [but to] make intentional efforts to diversify its workforce ..." (see textbook: Harrison, Harris, \& Tolchin, 2009, p. 198), which stresses the 1995 Clinton directive.

Moving beyond the quota myth to challenge the issue of meritocracy, one author argued that "Whites have long benefitted from unstated preferences as fraternity brothers, golfing buddies, children of alumni and the like - unconscious biases that go largely unrecognized until affirmative action forces recruiters to think about how they gravitate toward people like themselves" (see textbook: Barbour \& Wright, 2014, p. 198). Similarly, one author highlighted the benign use of quotas by mentioning

similar bonus points [as challenged in the Michigan cases] were also awarded to white students in other categories, such as recruited athletes, offspring of university alumni and residents of the Michigan's Upper Peninsula, an 
underrepresented group composed almost exclusively of white applicants. (See textbook: Shea, Green, \& Smith, 2007, p. 206)

By incorporating such important information, these authors demonstrated how quotas are viewed as socially acceptable when applied to legacy admissions or race privilege.

We found the terms reverse discrimination or reverse racism in $57 \%$ of the American government textbooks. Because the reverse racism argument rests on the notion that it is a form of racial discrimination, the very mention often "provokes division and reduces the ability of students to see 'across' racial lines and look 'into' the issue without vitriol" causing many students to frame their opinions racially (Gayles, 2004, p. 42). For example, one author defines "reverse discrimination" as "the situation in which affirmative action program discriminates against those who do not have minority status" (see textbook: Bardes, Shelley \& Schmidt, 2010, p. 172) while ignoring substantive evidence that could counter this argument, allowing those who make the claim of reverse racism to assert "Whiteness as disadvantage, something which has few precedents in U.S. racial history . . . [and] is absent of 'racial realism" (Gayles, 2004, p. 45). Only one textbook author debunks the reverse racism myth by asserting that "research indicates that gains for disadvantaged groups come with only small costs to white males" (see textbook: Losco \& Baker, 2010, p. 108). Perhaps, this occurs because most of the affirmative action discussions in American government textbooks are presented as mutually exclusive "pro and con" or "equal opportunity versus equal results" points of view, situated in a "color-blind society," yet hidden in coded language that is often racially dichotomized, gender-exclusive, and the "public" is "credited as praising abandonment of affirmative action" (Beeman et al., 2000, p. 108).

Words such as preferential and compensatory treatment are mentioned in $81 \%$ of the American government textbooks in our study, with 53\% implying that affirmative action has given "unfair advantages over whites" in a "colorblind society" on what should be based on individual "merit." Consequently, in most (66\%) of the textbooks, affirmative action discussions were presented as "equal opportunity" versus "equal outcomes." As Garcia Bedolla (2014) argues, debates about "equality of treatment, if built upon an unequal foundation, will by definition lead to inequality of result" (p. 452). Nevertheless, placed within the context of how best to eliminate or remedy historical discrimination, "equal opportunity" was associated with the liberal point of view while "equal outcome" was associated with the conservative point of view. Because the majority of textbooks presented the debates as racially dichotomized without challenging affirmative action myths and meritocracy, 
students are left to form their own opinions based on the balance of the arguments made by the textbook authors, which also provided key insights into where the textbook authors stand on the issue.

Many authors used the "equal opportunity vs. equal outcome" framework to deliberately represent liberal versus conservative positions:

Proponents argued in allowing minority candidates to compete on a more level playing field by tilting the field in their favor would produce equality. Opponents argued reverse discrimination would deny those benefits to other, more deserving candidates who had not themselves discriminated against minorities. In other words, equality of results for minorities took away equality of opportunity for majority applicants. (See textbook: Berman \& Murphy, 2007, p. 511)

Although "minority" can imply race or gender, the policy is clearly presented as a race-based program that promotes reverse discrimination and negates meritocracy. Further, the use of "deserving candidates" is coded language used to imply that affirmative action is unfair to Whites, strongly suggesting that the policy is "morally" wrong.

Another liberal versus conservative argument can be found in another textbook, where the author suggests that proponents of affirmative action argue that it

will allow women and minorities to receive equal treatment in the job market to which they are entitled ... [However] opponents say that aggressive affirmative action [policy] infringes unreasonably on the liberty of the employer and the initiative of the work force. (See textbook: Patterson, 2005, pp. 17-18)

Although the socially responsible, liberal argument is included in the discussion, the use of strong adjectives - "aggressive" and "unreasonably" endorses the principles of liberty and individual freedom (i.e., meritocracy) hailed by the morally-right, conservatives, which gives more credence to the opposing position and suggests that affirmative action should be curtailed. One textbook author argues that

proponents of race and gender-based preferences believe they are necessary to remedy the effects of past discrimination ... opponents of racial and gender preferences argue that the only fair way to determine college admissions and employment is merit. It is wrong, they say, to hire or promote someone because of race and gender. (See textbook: Tannahill, 2006, p. 538)

While both sides of the argument are presented, the emphasis rests on the side of the opponents. The authors of one textbook provide the "unconscious 
bias," liberal defense, conceding that "Proponents argue that what constitutes merit is highly subjective and embod[ies] prejudices of which the decision maker may be quite unaware" (see textbook: Edwards, Wattenberg, \& Lineberry, 2006, p. 158), but such argument is weak compared with the strong moral authority ascribed to the conservative view, which is based on the principle of individualism and merit, posited in affirmative action debates.

Roughly, seven of American government textbook authors used coded language of "less qualified" versus "better qualified" to present opposing views on affirmative action. Such distorted presentations, which surreptitiously promote the racist view of the Black inferiority, are made without evidence. In this vein, the liberal view advocates for the "less qualified" individuals while the conservative view asserts that only the "best qualified" individuals should receive consideration when it comes to educational, employment, and government contracts decisions. The authors of one textbook pressed that "not everyone agrees that affirmative action is a wise or fair policy" and that "opposition is strong in the case of individuals ... who are blameless [even though] less qualified individuals are hired or admitted to educational or training programs because of their minority status" (see textbook: Edwards et al., 2006, p. 158). When this view is decoded, we see that the "opposition" who are "blameless" are often Whites - unfairly passed over for less qualified "minorities" - yet no evidence is presented to substantiate this claim.

Another textbook author asserts that affirmative action is "popular" when it is used to "recruit and encourage qualified minority students," but when it "include[s] preferences for minority applicants over equally or better qualified non-minorities, public support falters ..." (see textbook: Dye, 2005, p. 554). This author does not explain who "the public" is or its views on race equality. Similarly, other textbook authors assert that even if affirmative action has "succeeded as policy for integrating the federal workforce," opponents still view the policy as "favoring minority applicants who have lower civil service test scores than whites" (see textbook: Landy \& Milkis, 2008, p. 539), which has "outraged blue-color Americans" (see textbook: O'Conner $\&$ Sabato, 2006, p. 229), which is an implicit reference to the deserving White working class. One textbook author even asserts that quotas are "psychologically damaging to members of minority groups" and amount to "illegal discrimination" (see textbook: Volkomer, 2006, p. 320).

Authors of another textbook invoke sympathy for the opponents of affirmative action, who are viewed by proponents as

heartless individualists, who would let other Americans remain in poverty because they lack the talent, luck or education to rise above it . . but opponents of affirmative action argue that such programs perpetuate unequal treatment 
and emphasize racial divisions in society. (See textbook: Sidlow \& Henschen, 2006, p. 28)

With no substantive evidence presented to support their claims, students are left to accept the textbook authors' arguments that Whites, in general, are innocent and are treated unfairly while Blacks or other underrepresented groups are simply inferior yet receive special consideration as opposed to equal treatment. For example, the "innate inferiority thesis" is woefully distorted in one textbook:

[Proponents argue that the] burdens of racism and sexism can be overcome only by taking race or sex into account in designing remedies. It is not enough to give rights to people; they must be given benefits. . . This means that that Constitution is not or should not be color-blind or sex-neutral. . . . In hiring it means that affirmative action - preferential hiring practices - must be used to find and hire women, African Americans and other minorities. Women should not simply be free to enter the labor force; they should be given the material necessities (for example, free daycare) that will help them enter it. On payday workers' checks should reflect not just the results of people's competing in the marketplace but the results of plans designed to ensure that people earn comparable amounts for comparable jobs. . . [Opponents hold] that if it is wrong to discriminate against African Americans and women, it is equally wrong to give them preferential treatment over other groups. To do so constitutes reverse discrimination. The Constitution should be color-blind and sex-neutral . . . using numerical targets and goals to place minorities and women in specific jobs is wrong. If people wish to compete in the market, they should be satisfied with the market verdict concerning the worth of their work. (See textbook: Wilson \& Dilulio, 2008, pp. 140-141)

Notably, two American government textbooks included opposing views on affirmative action within racial groups. Textbook authors Barbour and Wright (2014) presented the discussion this way:

[o]n the one side is a version of an American whose discriminatory past is past and whose job today is to treat all citizens the same. This view, shared by many minorities as well as many white Americans, argues that providing a set of lower standards for some groups is not fair to anybody. ... (p. 198)

While textbook authors, Lowi et al. (2013), surmised that the issue creates a "spiral of silence" within racial groups, arguing that even "African Americans dubious about affirmative action . . . come under considerable peer pressure and internal pressure to modify his/her views" (p. 392). These authors failed to discuss or present evidence on how the intersection of social 
categories of race, ethnicity, gender, and class can and do impact views about affirmative action. Only two of the American government textbooks link the overall policy intent of achieving "economic rights with civil rights" to similar policies of other nations, such India's constitutionally based affirmative action policy or Australia's and Canada's affirmative action measures that favor "positive discrimination" while avoiding "reverse discrimination" in promoting "equal outcome" with "equal opportunity" (see textbooks: Bardes et al., 2010, p. 173; Janda et al., 2005, p. 538). Such inclusion is instructive in dispelling affirmative action myths and individualistic, meritocratic views. More importantly, it acknowledges the need for legal action to address the historical, lingering effects of race and sex discrimination in the areas of education and employment in the United States.

Additionally, the most confusing discussions on affirmative action were in review of Supreme Court decisions. All 32 American government textbooks in this study used Supreme Court cases to discuss whether affirmative action programs were constitutionally permissible. We found that $82 \%$ of the textbooks presented the issue by asking whether "race-sensitive remedial measures" (Magleby et al., 2006, p. 455) - "because of the discriminatory nature" (see textbook: Bardes et al., 2010, p. 172) —violate the equal protection clause of the 14th Amendment. There were 12 citations of the important Adarand v. Peña (1995) decision that was the impetus for the basic policy principles that emerged from the Clinton administration's review (Beeman et al., 2000). Here, the court ruled that government institutions must employ "strict scrutiny" in using racial classifications and that programs must be "narrowly tailored" to not "unduly burden non-beneficiaries" or "trammel the interests of whites" and show "compelling interests" or legitimate government objectives for use (see textbooks: Beeman et al., 2000, p. 109; Lowi et al., 2013, p. 153; Morone \& Kersh, 2013, p. 199). Although most of the textbooks did not cite Adarand v. Peña (1995) by name, many incorporated the legalese found in the decision without full explanation as to what these terms actually mean with respect to affirmative action policy.

Mixed messages were abundant in discussions where authors attempted to explain judiciary collective ambivalence in decisions meant to achieve racial diversity in higher education. The authors of one textbook sought to contextualize the argument to show how the courts are "policymakers" who "rule differently in different parts of the country" with respect to affirmative action decisions, given that the United States Court of Appeals for the Fifth Circuit ruled that schools cannot use race preferences in admissions, while in the United States Court of Appeals for the Sixth Circuit, the rule allowed for race consideration; thus, such disagreements in appellate courts have to be decided by the Supreme Court (see textbook: Katznelson, Kesselman, \& Draper, 2006, p. 209). 
All but two (94\%) of the textbooks began by citing the nearly 40 -year-old Board of Regents of the University of California v. Bakke (1978) decision to discuss "reverse racism" or the permissibility of "quotas" in educational admissions. Beeman et al. (2000) point out that this kind of reference implies that affirmative action has "until recently been a quota program" (p. 109) when it was outlawed with that decision. The most common narrative recognized the desirability of a diverse student body that includes "educationally disadvantaged students," but the crux of the discussions was mainly structured to argue that "racial quotas violated the law; providing unfair advantages to minorities and unduly downgrading merit as the basis of social economic opportunities" (see textbook: Bond, Smith, \& Watson, 2006, p. 135). Thus, governmental institutions "cannot make use of quotas or preferences for unqualified persons" (see textbook: Bardes et al., 2010, p. 173) nor deny admission to White students (see textbook: Volkomer, 2006, p. 321 , which reinforces instead of challenges the quota myth or myth of meritocracy, for that matter.

The Texas cases-Hopwood v. University of Texas (1996) and Fisher v. University of Texas at Austin (2011) - combined were cited 15 times. The Michigan cases - Grutter v. Bollinger (2003) and Gratz v. Bollinger (2003)received a total of 28 citations alone, with frequent references (20 citations) to state referenda or ballot initiatives. These particular cases were often cited together to illustrate the latest Supreme Court decisions on affirmative action. The most common narrative was that the Supreme Court has ruled that affirmative action initiatives designed to achieve racial diversity in higher education "could not continue to admit minority students with lower grades and test scores" (see textbook: Miroff, Seidelman, \& Swanstrom, 2007, p. 508), but that programs can allow for a "selective index" based on "individualized consideration" or "individualized, holistic view" as long as it is not applied in a "mechanical way" that makes use of a "points system" or "special efforts" for race or other such "plus factors." Such discussions in American government textbooks tend to focus mostly on eliminating race-based affirmative action by stressing the need for a meritocratic approach. However, to clarify, Justice Ruth Bader Ginsburg, in her dissenting opinion for Fisher v. University of Texas at Austin (2011), argued that UT's admission policy treated race as merely one factor in the overall decision to admit a student and was permissible under previous judicial precedent. She went further to stress that the Equal Protection Clause does not require that state universities be blind to the history of overt discrimination and that it is preferable that they explicitly include race as a factor in admission decisions rather than attempt to obfuscate its role (Hannah-Jones, 2013), particularly given the historical, lingering effects of race discrimination. As Beeman et al. (2000) suggest, in analyzing 
the various Supreme Court decisions, critical debates can be centered on whether authority should be given to the federal government or the states to decide affirmative action policy or on how presidential administrations through the use of executive orders, in the face of congressional inaction, have sought to shape affirmative action policy according to their ideological views about race, which remains largely unexplored in American government textbooks.

Table 2 is a proportional analysis that measures for statistically significant relationships between the categories and within each category in the sample given the mention of code words or phrases. First, to measure the significance between the larger population, we determined whether policy intent or policy interpretation was present using a $z$ score significance test. Causal relationship was observed for five (1-5) of the seven categories. We observed a high statistical significance at .01 when affirmative action policy is mentioned in Category 1, with a higher proportion leaning toward policy interpretation. Category 2 was statistically significant at .10 with policy intent textbooks using less of this terminology. We observed a statistical significance at .05 for Categories 3 and 4, which were more likely to be found in policy intent textbooks as well; however, mentions in Category 5 were more likely to be found in policy interpretation textbooks. Second, when testing for statistical significant relationships based on the proportional within each category (i.e., intent vs. interpretation) for the mention of code words or phrases, we found that four $(1,2,3$, and 4$)$ of the seven categories yielded a causal relationship at .05 and .01, respectively. For Category 1, policy intent textbooks were less likely to present the debate as a negative. Categories 2 and 3 revealed some statistical significance with higher proportion for policy interpretation textbooks. For Category 4, policy interpretation textbooks only were more likely to mention these phrases in affirmative action discussions. Finally, Categories 6 and 7 yielded only internal statistical significance, suggesting that the textbooks are roughly equivalent on these topics in discussions. Overall, we contend that textbooks that focus on policy intent are more likely to challenge affirmative action myths or meritocracy than those that focus on policy interpretation, which tend to reinforce negative views given the higher proportion in the use of more highly charged language.

\section{Conclusion}

In summary, we know that American government textbooks transmit declarative knowledge about our political system, play an important role in political socialization, and promote political participation among students; however, explicit messages about democratic norms are undermined by implicit 
Table 2. Mention of Code Words or Phrases in Affirmative Action Discussions by Policy Intent and Policy Interpretation.

\begin{tabular}{|c|c|c|c|c|c|c|c|c|c|}
\hline \multirow[b]{2}{*}{ No. } & \multirow{2}{*}{$\begin{array}{c}\begin{array}{c}\text { Category of } \\
\text { mention(s) }\end{array} \\
\begin{array}{c}\text { Code words or } \\
\text { phrases }^{\mathrm{b}}\end{array}\end{array}$} & \multicolumn{2}{|c|}{ Intent } & \multicolumn{2}{|c|}{ Proportionala $^{a}$} & \multicolumn{2}{|c|}{ Interpretation } & \multicolumn{2}{|c|}{ Proportionala } \\
\hline & & Yes & No & Yes & No & Yes & No & Yes & No \\
\hline 1 & $\begin{array}{l}\text { Controversial } \\
\text { topic of } \\
\text { debate*** }\end{array}$ & 3 & 9 & .25 & $.75 * *$ & 13 & 6 & .68 & $.32 * *$ \\
\hline 2 & $\begin{array}{c}\text { Quotas, set-asides, } \\
\text { numerical goals* }\end{array}$ & 11 & I & .92 & $.08 * * * *$ & 18 & I & .95 & $.05 * * *$ \\
\hline 3 & $\begin{array}{l}\text { Reverse } \\
\text { discrimination or } \\
\text { reverse racism** }\end{array}$ & 3 & 9 & .25 & $.75 * *$ & 11 & 8 & .58 & .42 \\
\hline 4 & $\begin{array}{l}\text { Preference(s) } \\
\text { or preferential } \\
\text { treatment** }\end{array}$ & 8 & 4 & .67 & .33 & 17 & 2 & .89 & $.11 * * *$ \\
\hline 5 & $\begin{array}{l}\text { Un/fair advantage, } \\
\text { color-blind } \\
\text { society, } \\
\text { qualifications, } \\
\text { merit-based** }\end{array}$ & 5 & 7 & .42 & .58 & 12 & 7 & .63 & .37 \\
\hline 6 & $\begin{array}{l}\text { Equal opportunity } \\
\text { (EO)/equal } \\
\text { results (ER) }\end{array}$ & 9 & 3 & .75 & $.25 * *$ & 13 & 6 & .68 & $.32^{* *}$ \\
\hline 7 & $\begin{array}{l}\text { Equal Protection } \\
\text { Clause or I4th } \\
\text { Amendment } \\
\text { violation }\end{array}$ & 10 & 2 & .83 & $.17 * * *$ & 16 & 3 & .84 & $.16 * * *$ \\
\hline
\end{tabular}

Note. The asterisk(s) refer(s) to the level of statistically significant relationship between or within the larger populations. Proportion is derived from the number of mentions within the textbooks in the sample.

aProportional results are the statistically significant relationship within each category mention (intent vs. interpretation) or subsample in the larger population in the sample of textbooks. ${ }^{b}$ Code words or phrases are the statistically significant relationships between the category mentions (intent vs. interpretation) in the larger population in the sample of textbooks. Statistical significance levels: $*_{p}<.10 . * * p<.05$. $* * * p<.01$.

messages students receive regarding legitimate policy responses to eliminate historical, institutional, and structural barriers affecting underrepresented or marginalize groups (Cassese et al., 2014). In fact, such messages work against cultural awareness and inclusiveness. Our findings extend Wallace and Clayton (2009) and support Beeman et al.'s (2000) analyses. We conclude that 
the majority of discussions on affirmative action policy fail to address common misconceptions about the policy itself and, in effect, perpetuate the prevailing myths and meritocracy. We offer that a clear definition of affirmative action policy intent, grounded in modern racism theory, would help address the confusion students may have about the policy. Also, we recommend that textbook authors become self-reflective on the messages they transmit and challenge the widespread myths about affirmative action by simply incorporating the new guidelines established by the Clinton directive and by emphasizing Supreme Court cases where the use of quotas have been eliminated, yet while legal efforts are still deemed necessary to level the playing field. This study highlights the contextual nature of how affirmative action debates are presented in American government introductory textbooks, which, left unchallenged, can bias what students learn about the intent of the policy itself.

\section{Appendix}

American Government Textbooks Used in the Study.

I. Barbour, C., \& Wright, G. C. (with Streb, M. J., \& Wolf, M. R.). (20I4). Keeping the republic: Power and citizenship in American politics (6th ed.). Washington, DC: CQ Press.

2. Bardes, B., Shelley, M., \& Schmidt, S. (2006). American government and politics today (2006-2007th ed.). Belmont, CA: Thomson Higher Education. (20062007 Brief Edition, 2007)

3. Berman, L., \& Murphy, B. A. (2007). Approaching democracy (5th ed.). New York, NY: Pearson.

4. Bond, J. R., Smith, K. B., \& Watson, R. A. (2006). The promise and performance of American democracy (7th ed.). Belmont, CA: Thomson Learning.

5. Dautrich, K., \& Yalof, D. A. (2009). American government: Historical, popular \& global perspectives (Alternate ed.). Belmont, CA: Wadsworth.

6. Dye, T., \& Zeigler, H. (2006). The irony of democracy: An uncommon introduction to American politics (I3th ed.). Belmont, CA: Thomson Wadsworth.

7. Dye, T. (2005). Politics in America (6th ed.). New York, NY: Pearson.

8. Edwards, G., III, Wattenberg, M., \& Lineberry, R. (2006). Government in America: People, politics, and policy (I 2th ed.). New York, NY: Pearson Longman. (Brief 8th ed., 2006)

9. Fiorina, M., Peterson, P., \& Voss, S. (2005). America's new democracy (4th ed.). New York, NY: Pearson Education.

10. Ginsberg, B., Lowi, T. J., \& Weir, M. (20I3). We the people (9th Shorter ed.). New York, NY: W.W. Norton.

II. Harrison, B. C., Harris, J. W., \& Tolchin, S. J. (with Samuels, S. U., \& Bennion, E.). (2009). American democracy now (Ist ed.). Boston, MA: McGraw-Hill.

12. Janda, K., Berry, J., \& Goldman, J. (2005). The challenge of democracy: Government in America (8th ed.). New York, NY: Houghton Mifflin. 


\section{Appendix (continued)}

13. Jillson, C. (20I3). American government: Political change and institutional development (7th ed.). Belmont, CA: Thomson Learning.

14. Katznelson, I., Kesselman, M., \& Draper, A. (2006). The politics of power: A critical introduction to American government (5th ed.). Belmont, CA: Thomson Learning.

15. Kernell, S., \& Jacobson, G. (2006). The logic of American politics (3rd ed.). Washington, DC: CQ Press.

16. Landy, M., \& Milkis, S. M. (2008). American government: Balancing democracy and rights (2nd ed.). New York, NY: Cambridge Press.

17. Losco, J., \& Baker, R. (20I0). AM GOV (Ist ed.). Boston, MA: McGraw-Hill.

18. Lowi, T., Ginsberg, B., Shepsle, K., \& Ansolabehere, S. (20I3). American government: Power and purpose (13th ed.). New York, NY: W.W. Norton.

19. Magleby, D., O’Brien, D., Light, P., Burns, J. M., Peltason, J. W., \& Cronin, T. (2006). Government by the people (2I st ed.). Upper Saddle River, NJ: Prentice Hall.

20. McClain, P. D., \& Tauber, S. C. (20I4). American government in Black and White (2nd ed.). New York, NY: Oxford University Press.

21. Miroff, B., Seidelman, R., \& Swanstrom, T. (2007). The democratic debate: An introduction to American politics (4th ed.). New York, NY: Houghton Mifflin.

22. Morone, J. A., \& Kersh, R. (20I3). By the people: Debating American government (Ist ed.). New York, NY: Oxford University Press.

23. O'Connor, K., \& Sabato, L. (2006). American government: Continuity and change (8th ed.). New York, NY: Pearson Longman.

24. Patterson, T. (2005). The American democracy (7th ed.). Boston, MA: McGraw-Hill.

25. Shea, D. M., Green, J. C., \& Smith, C. E. (2007). Living democracy (National ed.). Upper Saddle River, NJ: Pearson.

26. Sidlow, E., \& Henschen, B. (2006). America at odds (5th ed.). Belmont, CA: Thomson Learning.

27. Spitzer, R. J., Ginsberg, B., Lowi, T. J., \& Weir, M. (2006). Essentials of American politics (2nd ed.). New York, NY: W.W. Norton.

28. Stephenson, D. G., Jr., Bresler, R. J., Friedrich, R. J., Karlesky, J. J., \& Turner, C. C. (2005). Introduction to American government (3rd ed.). Reno, Nevada: Best Value Textbooks.

29. Tannahill, N. (2006). American government: Policy and politics (8th ed.). New York, NY: Pearson Longman.

30. Volkomer, W. (2006). American government (I I th ed.). Upper Saddle River, NJ: Prentice Hall.

3I. Welch, S., Gruhl, J., Comer, J., \& Rigdon, S. (20I4). American government (I4th ed.). Belmont, CA: Wadsworth.

32. Wilson, J. Q., \& Dilulio, J. J., Jr. (2008). American government (I I th ed.). New York, NY: Houghton Mifflin.

Textbook publishers with number of editions in sample: Best Value Textbooks (I); CQ Press (2); Cambridge Press (1); Houghton Mifflin (3); McGraw-Hill (3); Oxford University Press (2); Pearson Group includes: Pearson Education, Inc; Pearson/Longman; Pearson/ Prentice Hall and Prentice Hall (9); Thomson Group includes: Thomson Higher Education; Thomson Learning; Thomson/Wadsworth and Wadsworth (8); WW Norton \& Company (3). 


\section{Declaration of Conflicting Interests}

The authors declared no potential conflicts of interest with respect to the research, authorship, and/or publication of this article.

\section{Funding}

The authors received no financial support for the research, authorship, and/or publication of this article.

\section{References}

Adarand v. Peña 515 U.S. 312 (1995).

Allen, M. D., \& Wallace, S. L. (2010). Teaching introduction to American government/politics: What we learn from the visual images in textbooks. Journal of Political Education, 6, 1-18.

Apple, M. W., \& Christian-Smith, L. K. (Eds.). (1991). The politics of the textbook. New York, NY: Routledge.

Artz, L., \& Murphy, B. O. (2000). Cultural hegemony in the United States. Thousand Oaks, CA: SAGE.

Bedolla, L. G. (2014). How an intersectional approach can help transform the university. Politics \& Gender, 10, 447-455.

Beeman, M., Chowdhry, G., \& Todd, K. (2000). Educating students about affirmative action: An analysis of university sociology texts. Teaching Sociology, 28, 98-115.

Bobo, L., Kluegel, J. R., \& Smith, R. A. (1997). Laissez-faire racism: The crystallization of a kinder, gentler, antiblack ideology. In S. A. Tuch \& J. K. Martin (Eds.), Racial attitudes in the 1990s: Continuity and change (pp. 15-42). Westport, CT: Praeger.

Cassese, E. C., \& Bos, A. L. (2013). A hidden curriculum? Examining the gender content in introductory-level political science textbooks. Politics \& Gender, 9, 214-223.

Cassese, E. C., Bos, A. L., \& Schneider, M. C. (2014). Whose American government? A quantitative analysis of gender and authorship in American politics texts. Journal of Political Science Education, 10, 253-272.

Clawson, R. A. (2003). Poor people, black faces: The portrayal of poverty in economics textbooks. Journal of Black Studies, 32, 352-361.

Clawson, R. A., \& Kegler, E. R. (2000). The "race coding" of poverty in American government college textbooks. The Howard Journal of Communications, 11, 179-188.

Clawson, R. A., \& Trice, R. (2000). Poverty as we know it: Media portrayals of the poor. Public Opinion Quarterly, 64, 53-64.

DiTomaso, N., Parks-Yancy, R., \& Post, C. (2011). White attitudes toward equal opportunity and affirmative action. Critical Sociology, 37, 615-629.

Eisenstein, M. A., \& Clark, A. K. (2013). Portraits of religion in introductory American government textbooks: Images of tolerance or intolerance. Journal of Political Science Education, 9, 89-107.

Ferree, M. M., \& Hall, E. J. (1996). Rethinking stratification from a feminist perspective: Gender, race, and class in mainstream textbooks. American Sociology Review, 61, 929-950. 
Fisher v. University of Texas at Austin 631 F. 3d 213 (5th Circuit 2011).

Foster, S. J. (1999). The struggle for American identity: Treatment of ethnic groups in United States history textbooks. History of Education, 28, 251-278.

Gainous, J. (2012). The new "new racism" thesis: Limited Glgovernment values and race-conscious policy attitudes. Journal of Black Studies, 43, 251-273.

Gayles, J. (2004). Standing in the right place: Engaging affirmative action in the classroom. Multicultural Education Journal, 12, 41-46.

Gratz v. Bollinger 539 U.S. 244 (2003).

Grutter v. Bollinger 539 U.S. 306 (2003).

Hannah-Jones, N. (2013, March 18). A colorblind constitution: What Abigail Fisher's affirmative action case is really about. ProPublica. Retrieved from http://www. propublica.org/article/a-colorblind-constitution-what-abigail-fishers-affirmative-action-case-is-r

Hardin, M., Dodd, J. E., \& Lauffer, K. (2006). Passing it on: The reinforcement of male hegemony in sports journalism textbooks. Mass Communication and Society, 9, 429-446.

Hogben, M., \& Waterman, C. K. (1997). Are all of your students represented in their textbooks? Teaching of Psychology, 24, 95-100.

Hopwood v. University of Texas 78 F. ed. 932 (5th Circuit 1996).

Hughes, M. (1997). Symbolic racism, old-fashioned racism, and whites opposition to affirmative action. In S. A. Tuch \& J. K. Martin (Eds.), Racial attitudes in the 1990s: Continuity and change (pp. 45-75). Westport, CT: Praeger.

Kinder, D. R., \& Sanders, L. M. (1996). Divided by color: Racial politics and democratic ideals. Chicago, IL: University of Chicago Press.

Kinder, D. R., \& Sears, D. O. (1981). Prejudice and politics: Symbolic racism versus racial threats to the good fife. Journal of Personality and Social Psychology, 40, 414-431.

Kluegel, J. (1990). Trends in whites' explanations of the black-white gap in socioeconomic status, 1977-1989. American Sociological Review, 55, 512-525.

Kolbe, R. H., \& Burnett, M. S. (1991). Content analysis research: An examination of applications with directives for improving research reliability and objectivity. Journal of Consumer Research, 18, 243-250.

Larew, J. (1991). Why are droves of unqualified, unprepared kids getting into our top colleges? Because their dads are alumni. The Washington Monthly, June. Reprinted in K.E. Rosenblum \& T.C. Travis (Eds.), The meaning of difference: American constructions of race, sex and gender, social class, sexual orientation and disability, (pp. 300-305). Boston, MA: McGraw Hill.

Monforti, J. L., \& McGlynn, A. (2010). Aquí estamos? A survey of Latino portrayal in introductory U.S. government and politics textbooks. Political Science \& Politics, 43, 309-316.

Myers, J. P., \& Stocks, J. L. (2010). Fostering the common good: The portrayal of the social economy in secondary business and economic textbooks. The Journal of Social Studies Research, 34, 266-303.

Olivo, C. (2012). The exclusion and inclusion of women in American government textbooks. In J. Hickman \& B.J. Porfilio (Eds.), The new politics of the textbook: Critical analysis in the core content areas (pp. 149-172). Boston, MA: Sense Publishers. 
Pettigrew, T. F. (1979). The ultimate attribution error: Extending Allport's cognitive analysis of prejudice. Personality and Social Psychology Bulletin, 5, 461-476.

Pincus, F. L. (1996). Test of affirmative action knowledge. Current World Leaders International Issues, 39, 94-104.

Plous, S. (2003). Ten myths about affirmative action. Journal of Social Issues, 52, 25-31.

Prestage, J. L. (1994). The case of African American women and politics. Political Science \& Politics, 27, 720-721.

Regents of the University of California v. Bakke 438 U.S. 265 (1978).

Samson, F. L. (2013). Altering public university admission standards to preserve white group position in the United States: Results from a laboratory experiment. Comparative Education Review, 57, 369-396.

Sander, R., \& Taylor, S., Jr. (2012). Mismatch: How affirmative action hurts students it's intended to help, and why universities won't admit it. New York, NY: Basic Books.

Schilling, J. (2006). On the pragmatics of qualitative assessment: Designing the process for content analysis. European Journal of Psychological Assessment, 22, 28-37.

Sleeter, C. E., \& Grant, C. A. (1991). Race, class, gender and disability in current textbooks. In M. W. Apple \& L. K. Christian-Smith (Eds.), The politics of the textbook (pp. 78-110). New York, NY: Routledge.

Sniderman, P., \& Piazza, T. (1993). The scare of race. Cambridge, MA: Belknap Press of Harvard University Press.

Stephanopoulos, G., \& Edley, C., Jr. (1995). Affirmative action review: Report to the president. Washington, DC: U.S. Printing Office.

Stone, P. (1996). Ghettoized and marginalized: The coverage of racial and ethnic groups in introductory sociology texts. Teaching Sociology, 24, 356-363.

Wallace, S. L., \& Allen, M. D. (2008). Survey of African American portrayal in introductory textbooks in American government/politics: A report of the APSA standing committee on the status of blacks in the profession. Political Science \& Politics, 41, 153-160.

Wallace, S. L., \& Clayton, D. M. (2009). An examination of introductory political science textbooks: How inclusive is African American politics? The National Political Science Review, 12, 247-264.

\section{Author Biographies}

Sherri L. Wallace is professor in the Department of Political Science at the University of Louisville. She is co-author with Hanes Walton, Jr. and Robert C. Smith on the forthcoming, American Politics and the American Quest for Universal Freedom, $8 e$ (New York, NY: Routledge). Her teaching areas include African American Politics, American Politics, State Politics and Public Policy.

Marcus D. Allen is professor in the Department of Political Science and Urban Studies at CUNY, Stella and Charles Guttman Community College. He has published research on college textbook diversity and race and politics. His teaching area includes American Politics. 